\title{
A PÉNZÜGYI KULTÚRA ÉS TUDATOSSÁG MEGHATÁROZÁSA ÉS MAGYARORSZÁGI HELYZETE
}

\section{DEFINITION AND STATUS OF FINANCIAL LITERACY AND AWARENESS IN HUNGARY}

\author{
Szóka Károly ${ }^{11}$ \\ ${ }^{1}$ Közgazdasági és Nemzetközi Kapcsolatok Intézet, Lámfalussy Sándor Közgazdaságtudományi Kar, Soproni \\ Egyetem, Magyarország
}

\author{
Kulcsszavak: \\ pénzügyi kultúra és tudatosság \\ pénzügyi attitüd \\ oktatás \\ Keywords: \\ Financial literacy \\ Financial attitude \\ Education
}

\section{Összefoglalás}

A mai modern társadalmunkban a gazdasági, pénzügyi ügyek kezelésének képessége egyre fontosabbá válik. Ez igaz a befektetési és banki szakemberekre, de igaz mindenkire, akinek felelös döntéseket kell hoznia a mindennapok során, így már a fiatal felnőttekre is. A jó döntés meghozásnak képességét általában gazdasági kompetenciának, gazdasági múveltségnek vagy pénzügyi kultúrának nevezik. A pénzügyi kultúra meghatározásával és mérésével már régóta foglalkoznak magán, üzleti és állami intézmények és szervezetek, nemzeti és nemzetközi szinten is. Magyarországon is elindult már a pénzügyi edukáció, különbözö szektorokban, különbözö szereplőkkel. Az oktatásnak és a nevelésnek elvitathatatlan a szerepe ebben, meglátásom szerint, minél kisebb korban indítjuk ezt, annál eredményesebb. A tanulmányban áttekintjük a pénzügyi kultúra fogalomkörének lehetséges meghatározását, a magyarországi helyzetet és a fejlesztési utat.

Abstract

In our today's modern society, the ability to handle economic and financial issues is becoming increasingly important. This is true for investment and banking professionals, but it is true for everyone who has to make responsible decisions in their daily lives, including young adults. The ability to make a good decision is commonly referred to as economic competence, economic literacy, or financial literacy. Defining and measuring financial literacy has long been cared by private, business and public institutions and organizations, both nationally and internationally. Financial education has already started in Hungary, in different sectors, with different actors. The education and upbringing have an undisputed role of in this, in my view, the younger we start it, the more effective it is. In this study, we review the possible definition of the concept of financial literacy, the status in Hungary and the development path.

\footnotetext{
1 A publikáció az MNB támogatásával jött létre.

Dr. Szóka Károly, Tel.: +36 99518426 E-mail cím: szoka.karoly@uni-sopron.hu
} 


\section{Bevezetés, avagy fontos-e a pénzügyi kultúra}

Életünk utóbbi 15-20 évét sajnos több válság is érintette. Volt, amelyik kisebb, volt, amelyik nagyobb térségre terjedt ki, a legújabb pedig világméretü, és még koránt sincs vége. Észrevehető, hogy mindig akkor került előtérbe a pénzügyi kultúra, múveltség és tudatosság kérdésköre, amikor dekonjunktúra figyelhető meg a gazdaságokban. Gyorsan változó világunkban olyan fogalmakkal és jelenségekkel találkozunk, melyek még az átlagosnak tekinthető pénzügyi kulturális szinttel rendelkezők számára is néha fejtörést okoznak, bizony utána kell néznünk ennek vagy annak a kifejezésnek, terméknek.

Ilyen időszakokban különösen fontos a megfelelő pénzügyi tudás, illetve ennek fejlesztése. A gazdasági problémák akár sokkhatást is kiválthatnak a társadalomban, amelyek kiválthatják a gazdasági és politikai vezetők, valamint tudományos szakértők erőfeszítéseit [17]. Ezek az erőfeszítések szerencsére világszerte - így Magyarországon is - sokrétűek, és képesek arra, hogy felhívják a lakosság különböző csoportjainak (tanulók, szülők stb.) a figyelmét. Elmondható az is, hogy az állami szabályozás is erősebb lett, illetve a hitelintézetek is felismerték, hogy a pénzügyi tájékozottság szintjének növelése számukra is hasznos, mivel pénzügyileg képzett fogyasztók hoznak a jövőben fognak tudatos és helyes pénzügyi döntést hozni banki ügyeikkel kapcsolatban [18].

A pénzügyi tudatosság, valamint a pénzügyi kultúra mérésével és kutatásával sok szakértő és szervezet foglalkozik, nemzeti és nemzetközi szinten is. A tanulmányban szeretném körbejárni a pénzügyi kultúra fogalmi hátterét, fogalomkörét és a megközelítéseket. Tekintsük át időrendben a fontosabb kutatásokat és véleményeket, meghatározásokat. A teljeskörüségre ezen tanulmány keretében nem törekedtem, terjedelme korlátok miatt. A súlypont Magyarországon van, illetve azokon a ma már iránymutató kezdeményezéseken és kiadványokon (szervezeteken), melyekre büszkék lehetünk, és valóban hasznos, tevékeny részei a pénzügyi kultúra témakör fejlesztésének.

\section{A pénzügyi kultúra, és meghatározásának fejlődése}

A pénzügyi kultúrával kapcsolatos kutatások gyökerei a XX. század elejéig nyúlnak vissza. A pénzügyi tudatosság meghatározásáról, vizsgálatáról már az 1960-as években jelentek meg cikkek, elsőként Herbert Mahlon Jelly doktori disszertációja, 1958-ban. A kutatásokat ekkoriban főleg az angolszász országokban folytatták és a pénzügyi termékeknek a fogyasztókhoz való eljuttatására korlátozódtak. Később már más területek is a fókuszba kerültek, így nem is kell csodálkozni azon, hogy a pénzügyi kultúra definiálása is változott. Különböző kutatók és szervezetek mára már sokféleképpen határozták meg a pénzügyi kultúra és tudatosság fogalmát. Igazából már nem definícióban, hanem koncepcióban kell gondolkodni, mely magában foglalja a pénzügyi ismeretek megszerzését, a pénzügyekben való jártasságot és tapasztalatot, a pénzügyi készségeket és a pénzügyi tudatosságot is [4]. Ha megfigyeljük a kutatásokat, ezek mindegyike több - az előbb említett témakörre is kiterjed, komplexnek mondható kérdéskörökkel, mutatókkal operálnak. Az angolszász szakirodalomban a financial literacy, a financial education vagy a financial knowledge fogalmakkal is találkozhatunk, melyek mind kapcsolhatók a pénzügyi kultúrához, de e területek összekapcsolására nem létezik egységes definíció.

Mit is sorolhatunk akkor ebbe a témakörbe? Az OECD elemzései során méri fel tagországainak pénzügyi kultúráját, annak szintjét, a kutatásokban a lakosok pénzügyi tudását, magatartását és attitűdjét méri fel. A felmérés során erre maximum 21 pontot adható (ebből 7 a pénzügyi tudásra, 9 pont a pénzügyi magatartásra, és 5 pont az attitűdre, az elemzést lásd később). Az OECD a pénzügyi oktatást, a pénzügyi fogyasztóvédelmet és az innovatív pénzügyi integrációt a legmagasabb szakpolitikai szinten az egyének pénzügyi felhatalmazásának és a pénzügyi rendszer általános stabilitásának három alapvető összetevőjeként ismeri el [26]. Tehát három részből állítja össze és számolja a pénzügyi múveltséget, ezek hivatalos megfogalmazás szerint a pénzügyi ismeretek, a pénzügyi viselkedés és a pénzügyi attitűd, így az OECD meghatározása szerint a pénzügyi kultúra: „A pénzügyi kultúra a tudatosság, ismeretek, készségek, és viselkedések kombinációja, amelyekre szükség van a megalapozott pénzügyi döntések meghozatalához és végső soron az egyéni pénzügyi jólét eléréséhez." [1] 2018-ban az OECD kicsit módosított a pénzügyi múveltség fogalmán, mely szerint a „pénzügyi műveltség a szükséges tudás, tudatosság, attitűdök és magatartás kombinációja annak érdekében, hogy az egyén megfelelő pénzügyi döntéseket hozhasson, hogy így önmaga számára pénzügyi jólétet biztosíthasson.” [8] 
Johnson és Sherraden már 2007-ben felhívta a figyelmet arra, hogy felnőtt egy olyan generáció, mely a konjunkturális jólét miatt nem tanult meg bánni a pénzzel, nem tud, és nem is akar takarékoskodni, hiszen azt látta, tanulta, hogy minden hitelekkel. Ezért célszerü a fiatalabb nemzedéket is bevonni a családi pénzügyi döntések meghozatalába, melyet az pénzügyi irányultságú tárgyak, ismeretek tanulása során értenek meg. [16]

Magyarországon a Magyar Nemzeti Bank (MNB) az elsők között dolgozott ki átfogó definíciót, amely szerint „A pénzügyi ismeretek és készségek olyan szintje, amelynek segítségével az egyének képesek a tudatos és körültekintő döntéseikhez szükséges alapvető pénzügyi információkat azonosítani, majd azok megszerzése után azokat értelmezni, és ez alapján döntést hozni, felmérve döntésük lehetséges jövőbeni pénzügyi, illetve egyéb következményeit.” [20]

A pénzügyi kultúrát meglehetősen összetetten értékelték Hung és szerzőtársai 2009-ben. Szerintük a pénzügyi műveltség egy képesség, melyet kilencféleképpen lehet megközelíteni, a pénzügyi tudás, a pénzügyi folyamatok megértése, a pénzügyi tudás alkalmazásának képessége, a pénzügyi összefüggések ismerete, a megalapozott pénzügyi döntések meghozatalának képessége, az alapvető pénzügyi fogalmak ismerete, az alapvető pénzügyi döntések meghozatalának képessége, a megalapozott és tudatos döntések meghozatalának képessége és az egyszerű pénzügyi fogalmak ismerete mind része a pénzügyi kultúrának. Ezek alapján látható, hogy ez inkább gondolkodás, viselkedésmód, illetve koncepció, mintsem definíció, illetve szerintük a pénzügyi ismeretek oktatása pedig folyamatként értékelhető. [14]

Az Egyesült Államokban a pénzügyi műveltség később általánossá váló fogalma 1997-ben a Jump\$tart Coalition for Personal Financial Literacy nevü szervezet írásában jelenik meg, mely szerint „A pénzügyi müveltség a pénzügyi tudás és készség olyan irányú felhasználásának képessége, amely lehetővé teszi az egyén számára, hogy egész élete során megfelelő hatékonysággal menedzselje pénzügyeit, pénzügyi biztonságra tegyen szert.” [29]

Most a Z generáció ül a felsőoktatás padjaiban, így fontos megismernünk az ő gondolataikat is a témával kapcsolatban. Csiszárik-Kocsir és Garai-Fodor kutatása szerint hallgatók számára fontos, hogy boldogulásukat gyarapítani tudják a pénzügyi ismeretek tanulásával, azzal nő a pénzügyi tudatosságuk, képesek lesznek körültekintőbb döntést hozni pénzügyi befektetéssel vagy pénzügyi termékekkel kapcsolatban. Szintén fontosnak tartják ezáltal a felelőtlen, meg nem alapozott pénzügyi döntések elkerülését. Végezetül a megkérdezettek kétharmada szerint azért is fontos a pénzügyi háttértudás, mert ezáltal tudnak segíteni azoknak, akik tanácstalanok a pénzügyi döntéseik terén. [11]

Wutke és szerzőtársai szerint a gazdasági hozzáértés (kompetencia) és a pénzügyi kultúra fogalma csak lazán kapcsolódik egymáshoz. A gazdasági kompetenciát általában átfogóbbnak tekintik, mint a pénzügyi müveltséget. E kompetenciák növekvő relevanciája elsősorban azon társadalmi-gazdasági tényezők miatt alakult ki, melyek a modern - iparosodott - társadalmak fontos részei. Ilyenek a pénzügyi szolgáltatások és a munkaerőpiac szerkezeti változásai, a jóléti állam hanyatlása, valamint a demográfiai változások. Az elmúlt években megfigyelhető a kockázatok áthárítása a kormányoktól és a munkáltatóktól a munkavállalók és a fogyasztók felé, mint például a csökkentett állami nyugdíjak, vagy a csökkentett egészségügyi ellátások, illetve azok szintjén keresztül. Ez az egyénekre hárítja a jelenlegi és jövőbeli pénzügyi biztonságról való gondoskodás felelősségét. Hasonlóképpen, mint Folke és kutatótársai, ők is kiemelik, hogy a serdülőkorúak és a fiatal felnőttek pénzügy tudásszintjének emelése a fontos, mivel a fiatalabb generációk nagyobb valószínűséggel hoznak felnőttkorukban nagy pénzügyi kockázattal járó döntéseket, és fiatalabban, mint szüleik. Kutatásuk eredményei azt mutatták, hogy a képzések száma és a gazdasági kompetencia szintje korrelál. A tanulók gyenge közgazdasági teljesítménye - legalábbis részben - az oktatás hiányosságaira vezethető vissza, hiányzik belőle a pénzügyi-gazdasági tartalom. [31]

Ahogy már említettem, fontos a pénzügyi termékek ismerete, és bizony igaz, hogy a lakosság egyre többféle pénzügyi terméket lát, illetve vásárolhat meg. Manapság az egyes pénzügyi termékek komplexitása már olyan nagy, hogy kifejezetten kockázatosnak ítélhető meg. Emiatt is nagyon fontos a megfelelő pénzügyi múveltség, ha ez nincs, akkor az egyén magára maradt, magára van utalva, de amúgy is igaz, hogy mindenkinek növekvő öngondoskodási kényszerrel kell megbirkóznia. [6]

Csorba szerint a pénzügyi kultúra (financial culture) és a pénzügyi múveltség (financial literacy) kifejezések a magyar nyelvben közel állnak egymáshoz, közelebb, mint az angol nyelvben, és emiatt a magyar pénzügyi nyelvezetben a pénzügyi kultúra kifejezés vált használatossá mindkettő 
esetben. Ezt a tényt Magyar Nemzeti Bank deklarálta, így vált irányadóvá. Ez nem hibás, mivel a két terület részben át is fedi egymást. Ez látható abból is, hogy a pénzügyi kultúra egy része nem tárgyilagos, azaz lexikális tudás, hanem ennek a tudásnak az alkalmazása, és bizony létezik pénzügyi analfabetizmus is, ők azok, akik nem rendelkeznek elégséges pénzügyi múveltséggel. Nagyon fontos az oktatásnak, az iskolarendszernek a szocializáló hatása is, mivel ez a tudás-alkalmazás ennek során sajátítható el. Azok számára, akik már kikerültek az iskolapadból, más módon kell ezt a fejlesztést biztosítani, például felnőttképzéssel, tanfolyamokkal, esetleg tévés szpotok vagy blogok révén. Sajnos ez a „gyorstalpaló” nem a legjobb módszer - bár jobb, mint a semmi - a leghatékonyabb, a legnagyobb hatású az akár évekig tartó, lassú tempójú oktatás. [8]

Folke és kutatótársai 2019-ben elindítottak egy 35 kérdésből, illetve feladatból álló kutatást, mely többek között a matematikai képességet, a számológép használatát, nemet és a társadalmigazdasági státusz vizsgálta, mint kulcsfontosságú előrejelzőket a pénzügyi műveltséggel kapcsolatban. Az eredmények kiértékelése alapján elmondható, hogy a pénzügyi kultúra és tudatosságra irányuló oktatással a fiatalabb népességet célszerü megcélozni, mivel a jelentősebb pénzügyi döntések az élet korai szakaszában születnek, és ez például a továbbtanulás finanszírozása esetében nagy összegeket jelenthet. Folke és kutatótársai - és még sokan - Belfield és Clark munkásságára hivatkozva állítják, hogy az alacsonyabb pénzügyi ismeretekkel rendelkezők több hibásnak mondható, hosszú távú következményekkel járó döntést hoznak, valószínűsíthetőleg pénzügyi tudatosság nélkül. A rossz pénzügyi döntések egyik egy fö kockázati terepe a diákhitel, amely valójában növeli a gazdasági egyenlőtlenségeket a tanulmányaikat meghosszabbítani szándékozók körében, ami pont ellentétes a felsőoktatás tervezett hatásával. Ezért a fiatalok hosszú távú gazdasági jólétének megőrzését célzó oktatási és egyéb szakpolitikai kezdeményezések kidolgozásához elengedhetetlen egy olyan hatékony intézkedés, amely valóban képes megragadni a fiatalok pénzügyi ismereteinek alaphelyzetét, és fejleszteni azt. [10]

A fejezet végén, mintegy lezárásként az a véleményem, hogy a pénzügyi kultúra fogalmát az alábbi meghatározás tükrözi a legjobban: „A pénzügyi ismeretek és képességek olyan szintje, amelynek segítségével az egyének képesek az alapvető pénzügyi információkat értelmezni, tudatos döntéseket hozni, felmérve döntésük lehetséges jövőbeni pénzügyi következményeit.” [30]

\section{A pénzügyi kultúra magyarországi helyzete és fejlesztése}

Az OECD időnként felméri tagországok (26 ország) lakosságának a pénzügyi kulturális szintjét. A kutatás során olyan fogalmakra kérdeznek rá, mint az infláció, a kockázat és megtérülés kapcsolata, vagy a megtakarítások fontossága. A 2010-es OECD felmérés alapján a magyar lakosság a nemzetközi átlagnál magasabb szintű pénzügyi tudással rendelkezett, ugyanakkor a tudás gyakorlati alkalmazásában gyengébb. A 2015-ben megismételt felmérés szerint a pénzügyi műveltséget mérő komplex mutató értéke 12,3, ami a maximális 21 pontnak a 60 százaléka, az összes ország átlaga 12,7 pont, az OECD átlag: 13 pont. Ezzel 26 EU-s országból a középmezőnyben, a 14. helyen álltunk, viszont negatív hír, hogy megnőtt azoknak az aránya, akik később fizetik be a számlákat, és csökkent azoké, akik kiadásaikat csökkentik, azaz ebben az 5 évben csökkent a lakosság megfontoltságának, gondosságának, pénzügyi előrelátásának szintje, jelentősebb lett a „carpe diem” gondolatvilágúak aránya. [15] [21] A 2020-as OECD jelentés szerint, Magyarország 12,3-as pontszámot kapott ugyanannyit, mint 2015-ben -, mely a 12,7-es átlag alatt szerepel kicsivel. Csak egy pár példa: Ausztria 14,4; Németoszág 13,9; Lengyelország 13,1; Románia 11,2 pontot kapott. [26]

Az OECD pénzügyi kultúrára vonatkozó adatbázisa alapján Németh és kutatótársai létrehoztak egy pénzügyi sérülékenység indexet, mely demográfiai, attitűd- és viselkedési jellemzőkből áll. Az OECD 2018-as adatbázisának adatai alapján a mutató átlaga 2,88 (szórás=2,67), a lakosság 70\%-a kevesebb, mint három olyan választ jelölt be, ami sérülékenységre utal. A pénzügyi sérülékenységmutató szignifikánsan magasabb a nóknél $(3,05)$, mint a férfiaknál $(2,68)$, ennek oka a nemek közötti jövedelemkülönbségre épülő elégedetlenség és szorongásérzet. A képzettségi szint is különbségeket mutat, a legkevésbé sérülékenyek a felsőfokú végzettségűek $(1,69)$, és leginkább sérülékenyek a 8 általánosnál kevesebbet végzettek $(5,00)$. Kiemelendő, hogy a nyugdíjasok és a foglalkoztatottak pénzügyi sérülékenységi szintje azonos, miközben a jövedelmi szintjük jelentősen különbözik, a vállalkozóknak pedig alacsony a sérülékenysége, ami a 2020-ig tartó konjunktúrával hozható kapcsolatba. Megállapításaik alapján a pénzügyi sérülékenység kialakulása, megléte együtt jár a 
magas eladósodottsággal és más problémákkal. A jövedelem növekedése csökkenti ugyan a pénzügyi sérülékenységet, de a magasabb jövedelem nem növeli arányosan a pénzügyi tudatosságot, azaz a sérülékenység kialakulásának hátterében az aktuális vágyak elhalasztása, későbbre tolása jelentős tényező, tulajdonképpen a fogyasztás növelése egyből megjelenik a jövedelem növekedésével. Összefoglalva megállapítható, hogy minél inkább tudatos valaki pénzügyei kezelésében, illetve minél több pénzügyi terméket ismer és használ, annál kevésbé sérülékenyebb. [18] [24]

Szintén 2015-ben indult egy felmérés, melyet az Emberi Erőforrások Minisztériuma és a Nemzetgazdasági Minisztérium kezdeményezett. Ennek célja az volt, hogy feltérképezze az általános és középiskolákban folyó pénzügyi és vállalkozási ismeretek oktatásának gyakorlatát. Ez alapján látható, hogy a képzések nagy részét négy nagy szervezet fedi le, és ezeken a képzéseken felülreprezentáltak a közoktatásban tanulók. A képzések túlnyomó részt rövid időtartamúak, (túl) sok témát érintenek, illetve elmondható, hogy az állami költségvetésű szervezetek inkább a pénzügyi ismeretek átadására és a felelős pénzügyi döntések előkészítésére helyezik a hangsúlyt, a pénzintézetek pedig inkább a pénzügyi önismeret fejlesztésére, a pénzügyi ismeretek átadására és a pénzügyi kockázatok megismertetésére. Ebből a kutatásból is látszik, hogy egyelőre elégtelen a leginkább rászoruló felnőtt csoportok (alacsony jövedelemmel rendelkezők, munkanélküliek) pénzügyi oktatása, így ezen a téren még várnak ránk feladatok. [23]

Ezek miatt - is - a Parlament 2017 októberében elfogadta az 'Okosan a Pénzzel!' címet viselő programot, mellyel a Magyar Kormány a lakosság pénzügyi tudatosságának szeretné fejleszteni. Ez a fejlesztési stratégia 7 fó célt fogalmaz meg, többek között, a köznevelés rendszerén belüli valós pénzügyi edukáció lehetőségeinek megteremtése, erősítése és általánossá tétele, kötelező pénzügyi képzés bevezetése a felsőoktatásban, a lakosság öngondoskodási szemléletének, a pénzügyi termékekhez, pénzügyi alapszolgáltatásokhoz való hozzáférés és pénzügyi beilleszkedés mértékének növelése, stb. A fó cél az volt, hogy a pénzügyi oktatás bekerüljön a Nemzeti Alaptantervbe, így eljutva minden fiatalhoz. A programban a felnőtt lakosságra is gondoltak, a stratégia az oktatáson kívül a pénzügyi stressztűrő képesség erősítését és a pénzügyi szemlélet kialakítását is tartalmazza. Ez a stratégia hét éves idősávot (2017-2023) ölel fel, a célokat 2023-ra kell elérni. A kérdés az, hogy ezen mennyit változtat(ott) a pandémia, a kényszerü távoktatás és home office. Jelenleg azt várjuk, hogy az első évek lejártát követően az operatív testület visszamérje az eredményeket, értékelje az előrehaladást, és mindezeket beledolgozza a következő évek feladataiba. [22] A pandémia lehetőséget teremtett arra, hogy a pénzügyi szektor szereplői kiterjeszthessék digitális szolgáltatásaikat azokra az idősebb társadalmi rétegekre is, akik korábban megszokásaikhoz ragaszkodva nem voltak nyitottak a digitális pénzügyi megoldásokra. [28]

Az Állami Számvevőszék és kutatócsoportja 2020-ban megismételte a 2013-ban elvégzett kutatását, mely alapján megállapítható, hogy pénzügyileg tudatosabbak a felsőoktatási hallgatók, de a pénzügyi tájékozottságuk szintje nem változott. Az vehető észre, hogy a fiatalok túlértékelték pénzügyi-gazdasági ismereteiket, ám hasonlóan kockázatkerülők, mint 7 éve, vélhetően nem vállalnak fel olyan kockázatot, amely meghaladná az ítélőképességüket, és ugyanúgy fontos számukra, hogy legyen megtakarításuk, biztonsági tartalékjuk. Pozitív, hogy a vizsgált hallgatók egyaránt rendelkeznek rövid, közép és hosszú távú célokkal. Jövedelmüket vizsgálva, a forrás a munkabér, a zsebpénz, valamint az ösztöndíj, és szintén kedvezőnek értékelhető, hogy 2013-hoz képest nőtt azok aránya, akik rendszeresen tudnak megtakarítani, illetve a megtakarítások átlagértéke is emelkedett. A tanulmány, zárásként felhívja a figyelmet arra, hogy a pénzügyi kultúra és tudatosság szintjének további emelése érdekében az oktatás-nevelés során nagyobb figyelmet kell fordítani a pénzügyi ismeretek oktatásán túl azok gyakorlati alkalmazására. [3]

Semmiképpen sem mehetünk el azon fejlesztési kezdeményezések mellett, melyet különböző szervezetek, programok útján valósítanak meg. A Magyar Nemzeti Bank a társalapítója a 2008-ban létrehozott Pénziránytű Alapítványnak, emellett támogatója számos pénzügyi témájú programnak, ilyen például a Pénz7, vagy a Pénziránytű Oktatási Program. A Pénz7 nem más, mint egy tematikus hét, pénzügyi és vállalkozói témában, a középiskolákban minden év márciusban tartják, főszervezői a Pénziránytű Alapítvány és a Magyar Bankszövetség. A Pénziránytű Alapítvány egy 2008-ban, a Magyar Nemzeti Bank, a Magyar Bankszövetség és a Diákhitel Központ által alapított nonprofit közhasznú szervezet, létrehozásának célja a pénzügyi kultúra, tudatosság, fejlesztése, tankönyveket és példatárakat adnak ki. [2] Az OTP Fáy András Alapítványt az OTP Bank alapította, múködésének célja az általános és középiskolás tanulók gazdasági témájú oktatása és a pénzügyi tudatosságának 
fejlesztése. Az Alapítvány ingyenes digitális oktatási programot indított diákoknak, emellett képzéseket és vetélkedőket, táborokat szervez, illetve mecénásként jelenik meg hasonló programok és intézmények mögött. [27] Végül megemlítem még - a teljesség igénye nélkül - a K\&H Vigyázz, kész, pénz! pénzügyi vetélkedősorozatot, mely 2010-tôl múködik, és célja, hogy bevezesse a diákokat a pénzügy világába, segítsen a pénzügyi kultúra elterjedésében és fejlődésében. [19]

Egyetértek Fejes [9] javaslatával, miszerint a PÉNZ7 kezdeményezésnek nemcsak minél több középiskolába, hanem általános iskolába is el kellene jutnia, illetve Horváthné és Széles [13] javaslatával is, mely szerint is a pénzügyek gyakorlati hasznosíthatóságát már az általános iskolák 7. és 8. osztályában érdemes oktatni. Persze, az is fontos, hogy a figyelem, megértés, koherens struktúrába szervezése a már meglévő tudással legyen integrálva, és ehhez szükség van az eddig alkalmazott módszerek, eszközök megváltoztatására és felkészülés a digitális nemzedék jövőbeli oktatására. [12]

\section{4. Összegzés}

A globalizálódó, pénzügyek által vezérelt világban már-már alapképességnek számít a pénzügyi műveltségre épülő öngondoskodás és a pénzügyi termékek ismerete és használata. Azonban ezt a kompetenciát ki kell alakítani, fejleszteni és javítani kell. E feladatban kiemelt szerepe van az oktatási és szakképzési rendszernek, ahogy erre már voltak és lesznek is törekvések hazánkban is.

Azt hiszem, nem kell vitatkozni azon, hogy minden nagyobb kiterjedésű válság vagy járvány mint ahogy a jelenlegi pandémia is - nehezíti a pénzügyi tudatosság és a pénzügyi kultúra szintjének emelését. Sok kutatóval egyetértésben ennek a közoktatásban kellene megvalósulnia, és sajnos a pandémia alatt az oktatás néhol problémákkal küszködik, lelassult, és az online eszközök és lehetőségek igénybevétele sem múködik mindenhol megfelelően. Szerencsére öröm is van az üröm mellett, a köznevelés, szakképzés és felsőoktatás területén most van lehetőség van a digitális oktatásra való felkészültségének növelésére, és magára az átállásra. Szoktuk mondani, hogy már semmi sem lesz a régi, ez bizony így van. A digitális oktatás részben, egészben már meg fog maradni, ez mára már kiderült és bizonyos mértékig már be is épült az oktatási rendszerbe.

A pénzügyi kultúrába beletartoznak a pénzügyi piacok szereplői, és azok motivációi, viselkedése is, illetve minden olyan gazdaságon kívüli preferencia, érték vagy gondolkodásmód, mely meghatározza viselkedésüket. A XXI. században nagyon fontos a kockázattal szembeni attitüd, a bizalom (vagy éppen annak hiánya) és az informáltság problémája. Nap, mint nap találkozunk lehalt pénzügyi rendszerekkel, hackelésekkel, vagy éppen nem múködő webbanki szolgáltatásokkal. Az igaz, hogy a pénzügyi kultúra szintjét nem egyszerü mérni, de ez fontos feladata a szaktárcáknak, mivel a pénzügyi képzésnek prioritást kell kapnia társadalmi és gazdasági szinten is. Szociodemográfiai elemzések szerint az esélyegyenlőtlenség akadályozza a pénzügyi kultúra javulását, így a pénzügyi műveltség és kultúra témaköre egyszerre társadalmi és gazdasági kérdés, illetve feladat. [4]

A fiatal felnőtteket alapvető gazdasági kompetenciákkal kell felszerelni. Ennek a feladatnak a teljesítéséhez a tanároknak olyan oktatásban kell részesülniük, amely átfogó megértést biztosít számukra a releváns témákban. Ez magában foglalja annak szükségességét, hogy ne csak a jelenlegi közgazdasági követelményekkel foglalkozzanak, hanem az osztályban a gazdasági tanulási helyzeteket is meg kell vizsgálni, értékelni és kiválasztani a tanulók tiszteletével és figyelembevételével.

Véleményem szerint van még hova fejlődnünk, nem szabad hagyni, hogy az Y és Z, Alfa stb. generációk ne kapják meg a szükséges pénzügyi ismereteket. Ha ők már kiérnek a munka világába, akkor már késő lesz edukálni széles tömegeket. Ennek a fejlődésnek több útja is van, a már említetteken kívül, szerintem az általános iskolás kornál is fiatalabbak, azaz az óvodás korúak pénzügyi tudatosságának a megalapozása az egyik legfontosabb lépés, amit ha időben elkezdünk, akkor komoly esély van a pénzügyi kultúra és tudatosság szintkének emelésére Magyarországon.

\section{Irodalomjegyzék}

[1] Atkinson, A., F. Messy (2012): Measuring Financial Literacy: Results of the OECD / International Network on Financial Education (INFE) Pilot Study., OECD Working Papers on Finance, 
Insurance and Private Pensions, No. 15, OECD Publishing, Paris. [Online]. Available: https://doi.org/10.1787/5k9csfs9ofr4-en [Megtekintés: 18-Szept-2021].

[2] Állami Számvevőszék (2016): Kutatási jelentés. Pénzügyi kultúra fejlesztési programok felmérése. ISBN 978-615-5222-12-2 [Online]. Available: https://www.asz.hu/storage/files/files/Publikaciok/Elemzesek_tanulmanyok/2016/penzugyi _kult_fejl_programok.pdf?ctid=976 [Megtekintés: 18-Okt-2021].

[3] Állami Számvevőszék (2020): Kutatási jelentés. Felmérés a felsőoktatásban tanuló fiatalokpénzügyi kultúrájáról. ISBN: 978-615-5222-26-9 [Online]. Available: https://www.asz.hu/storage/files/files/elemzesek/2021/felsooktatas_penzugyikultura_20210 311.pdf?ctid=1259 [Megtekintés: 18-Okt-2019].

[4] Béres, D., Huzdik, K. (2012): A pénzügyi kultúra megjelenése makrogazdasági szinten. PÉNZÜGYI SZEMLE/PUBLIC FINANCE QUARTERLY LVII.: 3. pp. 322-336.

[5] Bárczi, J., Zéman, Z. (2015): A pénzügyi kultúra és annak anomáliái. POLGÁRI SZEMLE: GAZDASÁGI ÉS TÁRSADALMI FOLYÓIRAT 11:1-3 pp. 101-108.

[6] Botos, K., Botos, J., Béres, D., Csernák, J., Németh, E. (2016): Pénzügyi kultúra és kockázatvállalás a közép-alföldi háztartásokban. PÉNZÜGYI SZEMLE/PUBLIC FINANCE QUARTERLY 57:3 pp. 291-309.

[7] Csiszárik-Kocsir, Á.; Garai-Fodor, M. (2018): Miért fontos a pénzügyi ismeretek oktatása a Z generáció véleménye alapján? Polgári Szemle, 14. évf., 1-3. Sz., 2018, 107-119., DOI: 10.24307/psz.2018.0809

[8] Csorba, L. (2020): Pénzügyi kultúra és pénzügyi múveltség, a pénzügyi magatartás meghatározó tényezői. PÉNZÜGYI SZEMLE/PUBLIC FINANCE QUARTERLY 65:1. pp. 67-82.

[9] Fejes, J. K. (2020): A pénzügyi tudatosság formálásának lehetőségei a középfokú oktatásban. XIV. Soproni Pénzügyi Napok pénzügyi, adózási és számviteli konferencia konferenciakötete. Soproni Felsőoktatásért Alapítvány. ISBN 978-615-80230-6-1

[10] Folke, T., Gjorgjiovska, J., Paul, A., Jakob, L., \& Ruggeri, K. (2021). Asset: A new measure of economic and financial literacy. European Journal of Psychological Assessment, 37(1), pp. 6580. [Online]. Available: https://doi.org/10.1027/1015-5759/aooo575 [Megtekintés: 18-Okt2021].

[11] Garai-Fodor, M., Csiszárik-Kocsir, Á. (2018): Miért fontos a pénzügyi ismeretek oktatása a Z generáció véleménye alapján? POLGÁRI SZEMLE: GAZDASÁGI ÉS TÁRSADALMI FOLYÓIRAT 14:1-3 pp. 107-119.

[12] Hegedûs, M. (2020): Oktatási módszertanok átalakulóban. SZÁMVITEL ADÓ KÖNYVVIZSGÁLAT: SZAKMA 62:6 pp. 39-41. ISSN-1419-6956

[13] Horváthné Kökény A., Széles Zs. (2014): Mi befolyásolja a hazai lakosság megtakarítási döntéseit? PÉNZÜGYI SZEMLE/PUBLIC FINANCE QUARTERLY 59:4 pp. 457-475.

[14] Hung, A., Parker, A. M., Yoong, J. (2009): Defining and Measuring Financial Literacy. RAND Working Paper Series WR-708. [Online]. Available: https://ssrn.com/abstract=1498674, http://dx.doi.org/10.2139/ssrn.1498674 [Megtekintés: 10-Szept-2021].

[15] Jakocác, K., Németh, E. (2017): A pénzügyi kultúra nemzeti stratégiái: tapasztalatok és tanulságok. PRO PUBLICO BONO: MAGYAR KÖZIGAZGATÁS; A NEMZETI KÖZSZOLGÁLATI EGYETEM KÖZIGAZGATÁS-TUDOMÁNYI SZAKMAI FOLYÓIRATA:1 pp. 196-211.

[16] Johnson, E.; Sherraden, M. S. (2007): From Financial Literacy to Financial Capability Among Youth. The Journal of Sociology and Social Welfare, Vol. 34, No. 3, pp. 119-145.

[17] Kovács, L., Terták, E. (2019): Financial Literacy: Theory and Evidence. Bratislava, Szlovákia: Verlag Dashöfer, 150 p. ISBN: 9788081781209

[18] Kovács, T.; Szóka, K. (2020): A pénzügyi kultúra és pénzügyi tudatosság helyzete. In: Kovács, Tamás; Szóka, Károly (szerk.) XIV. Soproni Pénzügyi Napok: „Gazdaságvédelem és pénzügyi kiutak” pénzügyi, adózási és számviteli szakmai és tudományos konferencia: Konferenciakötet. Sopron, Magyarország: A Soproni Felsőoktatásért Alapítvány (2020) pp. 104-112.

[19] K\&H Vigyázz, kész, pénz! [Online]. Available: https://www.kh-vigyazzkeszpenz.hu/ [Megtekintés: 10-Okt-2021].

[20] Magyar Nemzeti Bank (2008): Együttmúködési megállapodás a pénzügyi kultúra fejlesztés $\begin{array}{lllll}\text { területén a PSZÁF és az MNB között. [Online]. Available: } & \end{array}$ 
www.mnb.hu/letoltes/o415mnbpszafmegallpodas-penzugyi-kultura-fejleszte.pdf [Megtekintés: 10-Okt-2021].

[21] Magyar Nemzeti Bank, Pénzügyminisztérium, Pénziránytű Alapítvány (2020): A pénzügyi tudatosság fejlesztése segíti a családok anyagi biztonságát is. MNB Sajtóközlemények. [Online]. Available: https://www.mnb.hu/sajtoszoba/sajtokozlemenyek/2020-evi-sajtokozlemenyek/apenzugyi-tudatossag-fejlesztese-segiti-a-csaladok-anyagi-biztonsagat-is [Megtekintés: 10-Okt2021].

[22] Magyarország Kormánya (2017): Pénzügyi tudatosság fejlesztésének stratégiája. [Online]. Available:

https://20152019.kormany.hu/download/5/39/2100o/P\%C3\%A9nz\%C3\%BCgyi\%2otudatoss\%C3\%A1g\%2 ofejleszt\%C3\%A9s\%C3\%A9nek\%2Ostrat\%C3\%A9gi\%C3\%A1ja.pdf [Megtekintés: 3-Nov-2O21].

[23] Németh, E., Jakovác, K., Mészáros, A., Kollár, P., Várpalotai, V. (2016): Insight and Blight Initiatives on Enhancing Financial Literacy in Hungary = Körkép és kórkép a pénzügyi kultúra fejlesztését célzó képzésekről. Pénzügyi Szemle 61: 3 pp. 407-428.

[24] Németh, E., Zsótér, B., Béres, D. (2020): A pénzügyi sérülékenység jellemzői a magyar lakosság körében az OECD 2018-as adatainak tükrében. Pénzügyi Szemle 65:2 pp. 281-308.

[25] OECD/INFE (2018): Toolkit for Measuring Financial Literacy and Financial Inclusion. [Online]. Available: http://www.oecd.org/financial/education/2018-INFE-FinLitMeasurement-Toolkit.pdf [Megtekintés: 10-Okt-2021].

[26] OECD/INFE (2020): International Survey of Adult Financial Literacy. [Online]. Available: www.oecd.org/financial/education/launchoftheoecdinfeglobalfinancialliteracysurveyreport.ht m [Megtekintés: 10-Okt-2021].

[27] OTP Fáy András Alapítvány. [Online]. Available: https://www.otpfayalapitvany.hu/web/home [Megtekintés: 10-Okt-2021].

[28] Póta Cs., P., Veres, M., Dávidházy G., Á., Becsky-Nagy P. (2021): Kényszeradta lehetőség a pénzügyi digitalizációban. Controller Info IX. Évf. 2021. különszám 2-7 DOI: 10.24387/CI.2021.különszám.1

[29] Stolper, O. A., Walter, A. (2017): Financial literacy, financial advice, and financial behavior. J Bus Econ 87, pp. 581-643. [Online]. Available: https://doi.org/10.1007/s11573-017-0853-9 [Megtekintés: 3-Nov-2021].

[30] Süge, Cs. (2010): A pénzügyi kultúra mérhetősége. In: Tompáné Dr. Daubner Katalin \& Dr. Miklós György (szerk.) Tudomány napi előadás. Tudományos mozaik 7. Második kötet. Kalocsa, Tomori Pál Főiskola. pp. 1-11.

[31] Wuttke, E.; Seifried, J.; Schumann, St. (2016): Economic competence and financial literacy of young adults. Status and challenges. Opladen; Berlin; Toronto: Verlag Barbara Budrich 2016, 235 S. - (Research in vocational education; 3) - DOI: 10.25656/01:12165 [Online]. Available: https://www.pedocs.de/frontdoor.php?la=en\&source_opus=12165 [Megtekintés: 10-Okt2021]. 